\title{
Surfaces
}

\section{THE AFFECT IN THE WORK OF JEAN-FRANÇOIS LYOTARD}

\section{Ron Katwan}

Volume 3, 1993

URI : https://id.erudit.org/iderudit/1065103ar

DOI : https://doi.org/10.7202/1065103ar

Aller au sommaire du numéro

Éditeur(s)

Les Presses de l’Université de Montréal

ISSN

1188-2492 (imprimé)

1200-5320 (numérique)

Découvrir la revue

Citer cet article

Katwan, R. (1993). THE AFFECT IN THE WORK OF JEAN-FRANÇOIS LYOTARD.

Surfaces, 3. https://doi.org/10.7202/1065103ar

\section{Résumé de l'article}

L'auteur tente d'élaborer les motivations philosophiques qui sous-tendent l'appropriation par Jean-François Lyotard du concept meta-psychologique freudien de l'affect. Chez Lyotard, l'affect servirait à la ré-interprétation d'abord du concept de l'inconscient, et ensuite, de l'idée de la victime.
Copyright (C) Ron Katwan, 1993

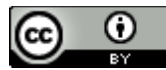

Ce document est protégé par la loi sur le droit d'auteur. L'utilisation des services d'Érudit (y compris la reproduction) est assujettie à sa politique d'utilisation que vous pouvez consulter en ligne.

https://apropos.erudit.org/fr/usagers/politique-dutilisation/ 


\title{
THE AFFECT IN THE WORK OF \\ JEAN-FRANçOIS LYOTARD
}

$\underline{\text { Ron Katwan }}$

\begin{abstract}
An interpretation of the philosophical motivations that drive Jean-François Lyotard's appropriation of Freud's metapsychological concept of the affect, which, in the author's view, serves two purposes: it reinterprets first the concept of the unconscious, and second the idea of the victim.
\end{abstract}

\section{RÉSUMÉ}

L'auteur tente d'élaborer les motivations philosophiques qui sous-tendent l'appropriation par Jean-François Lyotard du concept meta-psychologique freudien de l'affect. Chez Lyotard, l'affect servirait à la ré-interprétation d'abord du concept de l'inconscient, et ensuite, de l'idée de la victime.

This essay will provide an interpretation of the philosophical motivations that drive Jean-François Lyotard's appropriation of Freud's metapsychological concept of the affect. I will argue that the affect serves two purposes: it reinterprets first the concept of the unconscious, and second the idea of the victim.

In its first function the affect is the condition of the possibility of certain mental phenomena that are characterized by the subject's inability to be in control of its own thoughts and actions and by its incapacity to know what is happening to it. Consider the type of behavior that psychoanalysis has named "repetition compulsion", or the various forms of phobia and anxiety, 
as examples. Lyotard's claim is that these experiences cannot be understood as forms of representation, whether pictorial or linguistic. Rather, they point towards a passivity of the mind that is irreducible to the capacity to represent or articulate things. It is this aspect of mental experience that Lyotard designates by the term affect. The importance of the concept of the affect does not just lie in its ability to account for what some may regard as excesses of "normal" mental functioning. Rather, the "extraordinary" here provides access to a dimension of experience that is hidden from "ordinary" consciousness.[1] In order to do justice to these disruptions of consciousness, it is necessary to rethink our conception of experience so as to incorporate its affective component.

The second function of the affect is political: it is the condition of the possibility of distinguishing between forms of discourse that suppress otherness and those that are responsive to it. In The Differend Lyotard develops a conception of discourse that demolishes the idea of a subject or self that exists independently from the language and the society in which it is embedded. As a consequence it is no longer possible for Lyotard to define the suppressive power of certain forms of discourse as a violence committed against the "individual." Against this background, the affect emerges as a way of making sense of the notion of the victim of a radical wrong without recourse to the idea of an individual, self-identical subject. The affect becomes that in us which is suppressed by discourse, and which Lyotard calls us to be responsive to.

In section one of this essay I will present Lyotard's concept of the affect by working through the three antinomies to which it gives rise. In section two I will place the affect in relation to the problems surrounding Lyotard's notion of the "differend".

\section{1}

In order to understand Lyotard's concept of the affect, it is necessary to examine briefly the view that it challenges: the conception of experience as the representation of a self-conscious subject. This conception takes its departure from Kant's claim that the transcendental unity of apperception is the condition of the possibility of any experience. Experience requires the presence of a consciousness that guarantees the unity of representations over time. This unity is effected by the application of concepts which are rules organizing the manifold. For an activity of the subject to count as the application of rules, the subject has to be conscious of applying these rules; it has to know what it is doing.

Thus, three assumptions are made concerning the nature of experience. First, it is presupposed that self-consciousness, that is, the ability of the "I think" to accompany all representations, is a necessary condition of any experience. Second, it is asserted that in order to experience something, the 
subject has to be able to know what it experiences. This assumption follows from the first, that is, from the idea that representation depends upon the capacity for self-consciousness. Third, it is argued that experience has to be determined by rules. In other words, experience presupposes the ability to use concepts, or to speak a language.

If this definition of experience as self-conscious, rule-governed representation is taken to its last consequence, the idea of an experience in which the subject is not in control of itself, in the sense that it does not know what is happening to it, becomes incoherent: either something is represented under the constraints specified above, or it is not part of experience at all.

Lyotard's theory of phrases, as it is developed in the The Differend, is designed to redescribe experience so as to overcome its conceptual dependence on the notion of a self-identical, conscious subject.[2] In the terminology of The Differend the basic units of meaning are "phrases" that, for the most part, obey the rules of discourse. An articulate phrase (but as we will see not every phrase) presents a universe. That is to say, it usually relates the four poles of which the phrase consists to each other: the addressor who addresses a meaning about a referent to an addressee (Diff. $11,14)$. The four poles of the phrase universe do not precede as independent entities the phrase itself. Rather, they emerge only within the universe presented by the phrase and only in relation to each other.

What, in the tradition of Western philosophy, used to be the subject to which things are represented, is redescribed by Lyotard as the addressor of the articulate phrase. Unlike the subject, the addressor is not a self-conscious agent who constitutes experience through the application of rules. Rather, the rules of discourse precede and determine the individual consciousness (Diff. 71). Moreover, Lyotard states that phrases are separated from each other by a gap. The notion of the gap between phrases challenges the idea of a subject that is in possession of its experience, by bringing disparate representations into the unity of one self-consciousness. Instead of a unified whole of experience there are separate "events" of presentation (Diff. 77). For Lyotard experience or representation is not produced by consciousness but it occurs beyond the control of the subject.

The term "event of the phrase" thus designates a "dispossession of consciousness"[3]: as conscious beings we always already find ourselves implicated in a system of meanings determined by rules that are not our own. The emergence of experience, that is, what Lyotard calls the event of a phrase, has always already gone by, and necessarily remains hidden from our understanding. Thus, Lyotard's concept of the (articulate) phrase may be regarded as a polemic against the first two assumptions that defined the conception of experience as representation: first, the unity of selfconsciousness, and second, the capacity for knowledge of one's experience implicit in such self-consciousness. The third assumption regarding the 
transcendental necessity of rules for the possibility of any experience is what the concept of the affect will attack.

Lyotard defines the affect as an inarticulate phrase. The inarticulate phrase has only a meaning -- which is either pleasure or pain -- but lacks addressor, addressee and referent.[4] Thus, for Lyotard the silent affect designates the point where speech reaches its limits, where, in other words, it is confronted with its other. What, however, does it mean here to speak of the limits of discourse? It is crucial to realize that the affect must not be understood as an encounter with a transcendent, inexpressible reality, or with a thing-initself that falls irretrievably outside of the boundaries of our experience. For that would lead us back to the incoherent idea of the representation of the unrepresentable, or the knowledge of the unknowable. Lyotard's theory of phrases is meant precisely to provide a description of experience that goes beyond the oppositions of representation-thing, phenomenon-noumenon, and language-reality. These dichotomies are now replaced by the tension between an experience that is determined by rules and its anarchic disruption. This new opposition ought not to be regarded as an attempt to establish two independent and unrelated realms of experience. Rather, to the extent that it is a disruption of discourse, the affect can only manifest itself within the realm of that which it disrupts. In what follows, I will analyze the precise nature of the relationship between affect and articulate discourse, by formulating what I propose to call the three antinomies of affectivity.

The First Antinomy: according to Lyotard's conception of the inarticulate phrase, affective disruption brings about the disappearance of the addressor, that is, of what is commonly and misleadingly called the subject. Therefore, the idea that affects are private mental experiences taking place within the mental space of the subject is not available to Lyotard. How is it that pleasure and pain affect $m e$, the addressor of articulate phrases, even though they are not experiences of mine? If the disruption is not experienced by me, how is it that I perceive it as my experience?

If we are to insist on the idea that affects are experiences without a subject, that is, phrases without an addressor, we have to face the threat of rendering incoherent the idea that such feelings are our experiences. Since the affect is a pre-personal experience, the mere fact that the addressor of a phrase regards it as its own, seems to indicate that the affect has already become part of articulate speech. That is to say, just by ascribing the affect to itself the addressor has already responded to it within the realm of rulegoverned discourse. The presence of a conscious "I," necessarily presupposes the absence of the affect as a lived experience. If the feeling can become the object of philosophical inquiry it is because it has already gone by. Yet, although the affect is an experience in which the subject does not participate, the latter cannot help but regard it as its own and itself as affected by it. 
It is important to emphasize that the problem raised by the first antinomy cannot be countered by relying on Lyotard's redescription of experience in terms of phrases. The notion of the phrase served to overcome the dependence of experience on the continuous presence of a conscious, selfidentical subject. Without this reformulation of experience in terms of phrases, it would not even be possible to raise the problem of the relationship between inarticulate and articulate, for the idea of an inarticulate experience would be a conceptual impossibility. Rather, the question that is imposed on us by the first antinomy is the following: how is it possible that an articulate experience perceives itself to be responding, or, to be precise, to be forced to respond, to an inarticulate experience? Given that the "I" of articulate experience, that is, the addressor, is defined by the rules of articulate discourse, how can it experience itself as being claimed by something wholly inarticulate? In other words, how can what is radically heterogeneous exert any power over us at all?

Thus, in order to allow for the possibility of an affective experience, it is necessary to assume that the inarticulate and the articulate are intimately related to each other. The challenge posed to us now is how to think about this relation without recourse to either the unity of a self-consciousness, or the coherence of rule-governed discourse. Doing so involves taking into consideration the temporal structure of the affect, and will lead us to an encounter with a second antinomy.

The Second Antinomy: In the first part of Heidegger and the "jews"[5] Lyotard analyzes the temporality of the affect by means of the Freudian notion of "Nachträglichkeit", ("deferred action") (Heid. 15-17).

"Nachträglichkeit" describes the temporal relation between two mental events. There is a first event that the subject is incapable of experiencing because of its overwhelming, traumatic intensity. At a later time another, associatively connected, event triggers a response that is disproportionate to its minor significance in the agent's conscious life and that can, it seems, only be made sense of with reference to the first event. Although chronologically prior, the first event is only experienced after the second event and long after its own actual occurrence in chronological time.

Again we are confronted with a paradox: how can an event that has never been experienced, that has neither been understood by, nor been presented to consciousness, have these belated effects on the mind? Although the first event has never entered the consciousness of historical, chronological time, it inexplicably emerges within time in a paradoxical movement. The event that should have been prior, indeed must have been prior in order to produce its effects, appears to be brought about only by an event occurring long after it. It is not available to memory, and yet it is unexpectedly remembered or acted out.

To stretch the paradox even further, it is observed by Lyotard that it is precisely as missed, as gaps in ordinary experience, that certain events are 
capable of producing their unusual effects on the mental life of the subject (Heid. 12). Moreover, Lyotard writes: "We are confronted with a silence that does not make itself heard as a silence" (Heid. 12). The event is doubly missed. First, it overflows the capacity of the mind to represent it and therefore imprints itself on the mind only as a gap. Second, this gap in turn, by its very nature, does not manifest itself but is forgotten, or, to be more precise, repressed.

Freud tries to explain this phenomenon by means of the concept of the unconscious. The traditional interpretation of the unconscious runs roughly as follows: an experience, it appears, is, because of its intolerably painful nature, dissociated from the flow of the subject's conscious experience. However, it continues to exist unnoticed in the unconscious, as it were, until it suddenly interferes with the agent's ordinary activities. According to this theory, what is repressed into the realm of the unconscious is again a representation. However, a view that reduces the unconscious to representation cannot make sense of the disruptive force because of which what is unconscious has not just been forgotten but repressed. An unconscious representation could be brought to consciousness and thus be integrated into articulate experience. It could be controlled by discourse. There would be nothing threatening about representation alone. What is feared and therefore necessitates repression is the affect, that is, the disorder which it produces and which the conscious mind cannot tolerate.

Thus, Lyotard's conception of the affect is a reading of Freud's concept of the unconscious that rejects the idea that representations are present in a different, inaccessible mental space: if certain meanings take control of our minds against our will, it is because they were never present in us but were registered only negatively, as a violent silence. The affect designates the possibility of a "deep unconscious" (Heid. 11), that is, of an unconscious that is not capable of being made conscious and that defies the order of rulegoverned discourse. Caution is required here: as Freud maintains, and as Lyotard acknowledges, an affect can never strictly speaking be unconscious (Heid. 12). Rather, it is first registered as a shock without becoming an affect. It is too much to even be experienced as pleasure or pain. It becomes an affect only at a later occasion when it is no longer a shock. Of course, then it is no longer a "pure" affect but has already been responded to articulately.

I am using the term affect here in several senses. In one sense it is the silent gap that inscribes itself within the mind as a result of a shock. In another sense, it is the mind's response to the original shock through an experience of pleasure or pain. In the third sense, which is the one that I would like to propose as the primary one, the affective experience is neither just the shock nor just the affective response to it. Rather it is constituted by the temporal relation between the two. My reading of Lyotard thus maintains that the temporal structure of belatedness is not only a characteristic of certain pathological or traumatic experiences but is constitutive of the very nature of affectivity. To say this, I suggest, amounts to denying the possibility of a "pure" affect. The affect, in its silence, is something for which 
consciousness comes always too late. It becomes an experience only when responded to within the space of articulate discourse. The affective experience has a complex structure constituted by an enigmatic temporal relation between a disruption of experience and an interpretive and articulate response to it.

The Third Antinomy. The inarticulacy of feelings indicates that our being affected by events is an inexplicable fact. This inexplicability concerns neither the "real" situation that is experienced nor the mysterious existence of a private, inexpressible mental state. After all, there is nothing fundamentally problematic about establishing the factual situation that surrounds the event of being affected nor about the behavior of the agent that responds to it later on. For both are located within the public world opened up by the discursive order. What eludes understanding, however, is the dynamic of the temporal relation between the event of disruption and its incorporation into linguistically structured, conscious experience. Not only are we faced here with the enigma of how a gap, a nothingness, can inscribe itself within the mind, but, moreover we confront the paradoxical fact that this gap seems to possess specificity. The relationship between a disruption and its articulation is not arbitrary. How is it that the symptoms of the neurotic, the memories of the victim or the repetition compulsion of the survivors of traumas display a meaningful pattern that is obviously associated with a particular, earlier event? How do we account for this fact if the event was never experienced, never represented and never symbolically registered? In spite of its inarticulacy the affective disruption seems to be related to, and partly even to obey, the logic of speech. Furthermore, without this symbolic, associative tie, we would never be able even to discover the phenomenon of the after-effect for it is precisely the fact that we detect symbolic traces in a person's behavior that refer us back to an earlier incident that made us conceive of the notion of belatedness to begin with. Moreover, not every event affects us in the same way or to the same degree. In fact, in order to be able to distinguish between traumatic and ordinary emotional experience we often seem to be forced to use the quantitative term "too much" to describe the impact of reality on the psyche. Yet, such quantification appears to be entirely unwarranted given the radical inarticulacy of the affect. Thus, in order to accomplish the disruptive linkage between shock and symbolic response, the affect must be related to the discursive order and be its radical disruption.

The concept of the inarticulate phrase designates another "dispossession of consciousness" which consists in the affective disruption of articulate experience, and which accompanies the first movement of dispossession, indicated by the dispersion of the subject into disparate phrase universes. The path towards this second dispossession is already opened up by the notion of the "event of the phrase", that is, the gap that separates presentations from each other: to speak of the event of phrasing suggests that experience is not something that can be controlled by consciousness. It takes place without an author. Therefore, it is important to understand the relationship between the concepts of the event and the affect: like the event the affect is necessarily missed by discourse. The affect is an experience 
without content. It indicates to the mind that something has happened, but not what has happened. It could be said that it bears witness to the event of a phrase, that is, the taking place of an experience, without being able to speak of its nature.

Affectivity could also be called a faculty of mediation between an event and an articulate response to it. By mediation I do not mean a synthetic, unifying act of consciousness, but a temporal movement of postponement that links together by breaking apart. The event of affectedness and its articulation, to borrow an expres-sion from Lyotard, only "meet by missing each other" (Inart. 3). Affective mediation neither guarantees nor presupposes the unity of the subject over time. Rather, the notion of the affect suggests that the mind is constituted by a series of splits. Experiences are linked to each other by disruption. Irreducible to what may be called the capacity to follow rules, affectivity is characterized by a resistance against receiving the impact of discursive reality, an inherent stubbornness of the mind that refuses to let itself be integrated into any kind of discursive system. It marks the possibility of the suspension of linkages between phrases from within the mind, whenever, and for whatever reasons, reality becomes "too much" for the psychic apparatus to cope with.

The affect, though missed in its silence, manifests itself in the effects which it produces within the realm of conscious, articulate experience. In general, these effects consist in the interruption of linkages between phrases and the consequent emergence of new types of linkages, as it occurs for example in cases of creativity or "insanity." Affectivity is a capacity to deviate from the norm and to break the rules of discourse. New rules will always be found to retroactively make sense of what has inexplicably emerged there. But these rules do not from the outset determine the nature of this emergence. Moreover, such deviation is not a matter of decision. In affective experiences, we do not choose to disobey rules but momentarily loose our capacity to obey them.

The intimate relationship between affect and event indicates that the affect cannot be conceived of as an isolated experience. As a disruption of articulate discourse, it cannot be made sense of as existing apart from its relation to articulate phrases. Therefore, the affect must not be understood as an isolated experience. As the analysis of the three antinomies of affectivity suggests, the affect is constituted by a paradoxical temporal relation between a disruption of experience and an articulate response to it.

In this section I have presented the affect as the condition of the possibility of the phenomena of disruption of articulate experience. In the second section, I will analyze the political function of the affect in Lyotard's work, by locating it within the field of problems opened by the concept of the "differend". 
The "differend" is a dispute in which the legitimacy of the claims of one party is compatible with the legitimacy of the claims of the other party (Diff. $\mathrm{XI}$ ). There is a multiplicity of heterogeneous forms of discourse, which Lyotard calls "genres," that prescribe the rules for the linkages between phrases with reference to their ends. The legitimacy of these linkages can be justified only in terms of rules, and therefore only within a given genre. With regard to each phrase several linkages are possible, and there is no way of establishing which one of them is legitimate (Diff. XII).

In the context of politics, Lyotard's concept of the phrase indicates the impossibility of appealing to a universal, rational authority in matters of ethical and political disagreement: procedures for settling problems of legitimacy can only be specified according to the rules of a given genre (Diff. XII). They do not have the power of proving the illegitimacy of linkages demanded by other genres. Disputes between genres cannot be litigated, and hence result in a differend. Moreover, as I have shown above, the concept of the phrase demolishes the idea of a subject that exists apart from discourse. Therefore, since the "individual self" is but a segment of a phrase, its "freedom," "happiness" or "rationality" can no longer serve as a standard by which the justice or injustice of forms of discourse can be measured. Rather, what will count as a "free", "happy" or "rational" individual is defined by the rules of genres.

Let us consider the following type of differend: a social group that considers itself to be the victim of an injustice tries to establish the reality of a historical event, or to raise a moral concern. The rules of the discourse with which it is confronted, as represented by the other disputing party, do not allow it to express its complaint (Diff. 9). Its phrases are either ignored, or acquire a different meaning. In any case, they are not allowed to express the meaning that they possess for the victimized community. Thus, the victim's expression of suffering may be incorporated as as step in a "dialectical or historical development towards social progress" rather than a claim for truth in its own right, or it may be defined as an emotive utterance rather than the expression of a legitimate moral concern.

This description of victimization in which one of the disputing parties is said to be deprived of the means of voicing its complaint which it nevertheless is capable of formulating according to its own rules within its victimized community cannot be taken for granted. In order to establish a dispute as a differend, it is necessary to transcend the viewpoints taken by the disputing parties. From the disputing parties the event of a differend as such is hidden. The party which commits the wrong cannot acknowledge the differend because it is defined precisely by its attempt to reduce the other genre to its own rules, thereby ignoring its otherness. If it nevertheless senses the differend, this is not because it recognizes its nature but only because it feels a conflict (to which it then responds by trying to transform it into a litigation). The party of the victim, even if it does not necessarily deny the legitimacy of the discourse which has committed injustice to it has no 
way of proving, even to itself, that this legitimacy does not entail its own illegitimacy. Yet, it is affected by, feels without being able to explain or prove why, the wrong from which it suffers. It can be thrown into a state of selfdoubt and self-denial and of blind rage against what it perceives to be an unjust order. But in order to be able to see the differend for what it is, one must be able to stand back from the dispute by putting oneself into the position of the tribunal that is capable of acknowledging the legitimacy and hence incompatibility of both discourses.

From the viewpoint of a discourse that absolutizes its claims, the phrase that declares itself to be victimized by that discourse is always bound to be subsumed under the dominating rules. The differend can only be judged to be there from the hypothetical viewpoint of the tribunal the existence of which is precisely what the notion of the differend denies. The conditions under which the differend could be established are precisely the conditions under which the differend could be litigated and under which it would hence cease to be a differend. The moment a differend is established it becomes a mere dispute. The radical heterogeneity of genres cannot be proven. If there is a point of view from which judgement regarding the heterogeneity between discourses is possible, then what such judgement requires cannot be a proof that a wrong has occurred.

The notion of the differend, as it is articulated by the theory of phrases, raises another serious issue: given that there is no individual self apart from what appears as the addressor pole within the universe of a phrase, who or what is the victim of a wrong? If it is impossible to establish the legitimacy of the victim's own understanding of its phrase against the discourse that suppresses it, then it is impossible to establish that victimization has taken place at all. It is in this context that the affect acquires its importance in Lyotard's work: affects are produced by the differend, that is, they are the event of suffering from a radical injustice, and as such they are also signs of the occurrence of a differend.

Lyotard writes: "An articulate phrase and an affect-phrase can only meet by missing each other. A wrong results from their differend. If articulation and inarticulation are irreducible to one another, it can be said that this wrong is radical" (Inart. 3). What is it about the affect-phrase that accounts for this peculiar feature? If the affect-phrase does not present a universe, it follows that it has no phrase regimen and obeys no rules. Nevertheless, it can be made the referent of another phrase, that is, it can be presented. However, when it is thus presented it is already made part of the discursive realm to which it by its nature does not belong. Thus, regardless of what the rules are according to which the articulate phrase tries to explain the affect-phrase, it will first of all have to interpret the inarticulate as an articulate phrase, that is, as a phrase that is capable of obeying the rules of its genre. It is, however, the very act of linkage according to rules which is, for Lyotard, always an alien imposition on the affect-phrase. Between affect and articulation the differend is inevitable. 
Why does Lyotard insist on the radical inarticulacy of the affect? As has been shown in the first section of this paper, the theory of phrases leads to a "dispossession of consciousness" which consists in the disintegration of the subject into addressors of articulate phrases, defined by the rules of discourse. Now, in The Differend Lyotard argues that certain genres of articulate discourse have a tendency to suppress the heterogeneous and to subsume everything under its own rules. The human is subordinated to the interests of the system, that is, it becomes a function within the totality of discourse. Against this background we need to interpret Lyotard's insistence on preserving heterogeneity at any cost:

\section{pp.18-19/}

The interest of humans is subordinate in this to the survival of complexity. ... what else remains as 'politics' except resistance to this inhuman? And what else is left to resist with but the debt which each soul has contracted with the miserable and admirable indetermination from which it was born and does not cease to be born? -- which is to say the other inhuman?[6]

The affect has to be understood as that other "inhuman," that "second dispossession of consciousness," that comes to counteract the dehumanization of life through the totalization of discourse. While the concept of the articulate phrase, set in opposition to the idea of the subject's representation, indicates the incapacity of consciousness to be in control of the rules that determine the nature of its experience, the inarticulate stands for the inability of discourse to ground or explain experience by means of rules.

The heterogeneity of the affect finds its rationale in its importance for making sense of the event of victimization by certain forms of discourse: the affect designates the possibility of suffering a wrong without being a conscious subject, that is, the addressor of an articulate phrase. That it is possible to suffer from a wrong, presupposes that following rules is not a matter of course. If there is nothing in experience that resists obedience to rules, the absorption of experience into discourse, or the complete articulation of life, then there is no sense in which the totalizing claims of certain genres can be said to commit violence against human beings. In the absence of a universal rationality that can pass objective judgement on acts of injustice, and after the demolition of the independent subject whose freedom and individuality could pose limits on the power of rules, the affect comes to constitute the point of incommensurability between life and discourse. It is that which radically defies incorporation into a discursive system. Thus, the affect names that which suffers the violence that results from the suppression of heterogeneity by discourse. It is important to emphasize that suppression (and, as we will see, responsiveness) are attitudes that we not only adopt towards others, but also towards ourselves. The affect stands not just for the heterogeneity of other minds but also names the otherness that is inside of us. 
How does the radical inarticulacy of the affect allow it to be a sign of a "differend"? We have seen that the wrong produced by a differend cannot be established. It can be made visible within discourse only as a violent silence, that is, as an affect. However, because the affect is by its very nature a missed event we cannot prove that it has taken place. There can be no direct evidence of it. At the moment the affect is pointed to, or spoken of, it has already been made part of articulate experience. If we were able to establish its nature, it could no longer be what it is, that is, an experience for which inevitably we come too late. Moreover, in order for the event of suffering a wrong to become the basis of a complaint against a form of discourse, it has to be claimed by someone, that is, by an addressor. Yet, this act by which addressors claim the affect as their experience and thereby present themselves as victims is already an act of violence against the silence of the affective experience because it draws the affect into the realm of articulation.

The experience of victimization is paradoxical: on the one hand, the event of suffering a wrong brings about the disappearance of consciousness and articulation. It is radically silent. Therefore, if we can speak of it, we can not have experienced it. Talking about the inarticulate always involves testifying to something to which no one, neither we ourselves nor others, could possbly have been a witness. On the other hand, the compulsion to speak is constitutive of victimhood, for without articulation the event of suffering must remain a nothing. Suffering that does not affect anyone would not be suffering. Thus, to have been subjected to a radical wrong means to be forced to speak and simultaneously to be incapable of doing so. The affect is the experience of the irreconcilable conflict between an inevitable silence and an equally inevitable need to speak.

Victims can never prove, even to themselves, their victimization. The only way for them to bear witness to the injustice that they have suffered is to testify to their own inability to know what has happened to them. All that is left for them to do is to express their silence as silence, that is, to speak so as to make it audible that they cannot speak (Heid.47). It is precisely this articulate expression of the incapacity to testify that announces someone as a victim.

And yet, victims are unable to prove even this silence. That is to say, it is impossible for them to establish that their silence carries the meaning of a radical disruption. The discourse of the other party can either regard silence as a meaningless physical stillness, a lack of noise, as it were, or it can see in silence a form of speech that is capable of being articulated precisely because it is from the very beginning embedded in, and explainable in terms of, a communicative context. In neither case can the silence testify to a radical wrong. Suppression of heterogeneity does not just consist in a failure to respect the victim's point of view, but in denying that a wrong has occurred at all. The act of suppression does not understand itself as suppression. It is thus characterized by a denial of the possibility of the affective experience because of the paradoxes to which it gives rise: either 
the affect is inarticulate and then it cannot have any relevance to our experience, or it is articulate and then it is not a disruption of discourse but a form of participation in it. If it cannot be spoken of, it does not concern us. If it can be spoken of then it is not what it claims to be, that is, a disruption of discourse. Suffering a radical wrong becomes a conceptual impossibility.

Responsiveness to the affect involves taking seriously its paradoxical structure in which silence and articulation are, in spite of their radical incommensurability, inextricably linked. It is only from the viewpoint of a responsive attitude that sustains the paradoxicality of the event of victimization that suppression can become visible. Responsiveness to the event of suffering a wrong demands that we recognize the signs of a differend precisely in the collision of the victims' compulsion to speak of their suffering and their incapacity to testify to it.

Responsiveness to the affect is itself necessarily paradoxical. It demands that we open ourselves to an experience that is defined by its intolerability. It requires that we speak of what cannot be spoken of. Far from being a logical error, however, this irrationality of responsiveness is inseparable from what it means to be human. The human is lived in the paradoxical and intolerable tension between two "inhumans": affect and discourse. The temptation of each "inhuman" is to "resolve" the paradox and to "heal" the painful disorder caused through this conflict, by eliminating its other. Lyotard's philosophy calls upon us to resist this temptation.

\section{Ron Katwan}

Department of Philosophy

Yale University

Surface Page d'Acceuil/Home Page

[1]I am using quotation marks here to indicate that the opposition between ordinary and extraordinary is deceptive. For Lyotard the ordinary has always already been invaded by the extraordinary.

[2]Jean-François Lyotard, The Differend: Phrases in Dispute, trans. Georges Van Den Abeele (Minneapolis: University of Minnesota Press, 1988):

hereafter referred to as Diff. 
[3]I am borrowing this term from Paul Ricoeur, Freud and Philosophy (New Haven: Yale University Press, 1970), pp. 54-55.

[4]Lyotard, "The Inarticulate or the Differend Itself", trans. Thomas Cochran, Irene Wei (unpublished): Inart.

[5]Lyotard, Heidegger and the "jews", trans. Andreas Michel (Minneapolis: University of Minnesota Press, 1990): Heid.

[6] Lyotard, The Inhuman, trans. G Bennington and R. Bowlby (Stanford: Stanford University Press, 1991), p. 7. 